\title{
炭素繊維一樹脂複合繊維束の引張強度に及ぼす 樹脂特性の影響に関する考察
}

\author{
東京工業大学有機材料工学科 高久 明・塩谷正俊・清水二郎
}

\section{CONSIDERATION ON THE EFFECT OF RESIN PROPERTIES ON TENSILE STRENGTH OF CARBON FIBER-RESIN COMPOSITE STRANDS}

\author{
By Akira Takaku, Masatoshi Shioya and Jiro Shimizu
}

(Department of Textile and Polymeric Materials, Tokyo Institute of Technology, O-okayama, Meguro-ku, Tokyo, JAPAN.)

An equation which describes the effective tensile strength of fibers in a composite strand has been obtained from the consideration on a failure model assuming statistical accumulation of fiber fractures in a matrix with increasing load until a sufficient number of fractures occur at some crosssectional region of the strand. It is assumed that when a fiber in the composite strand breaks by increasing the load, a transmission of the stress along the fiber is to be intermitted by an ineffective length in the vicinity of the fracture point. The fibers in the composite strand are treated assuming a statistical strength distribution. It is also postulated that when a certain fiber in the composite strand breaks at a weak point of the fiber, some other fibers neighboring the fracture point break simultaneously and a total of $k$ fibers break at the same time. The ineffective fiber length $\delta$ and the effective tensile strength $\sigma_{c, b}$ of the fibers in the composite strand are given as

and

$$
\delta=\operatorname{Max}\left[\frac{2 \ln 2}{\beta}, \frac{R_{\mathrm{f}} \sigma_{f}}{2 \tau_{\mathrm{b}}}\right]
$$

$$
\sigma_{c, b}=\operatorname{Min}\left(\sigma_{\theta}\left\{\frac{\beta}{2(\ln 2) e \alpha k}\right\}^{\frac{1}{\alpha}}, \sigma_{\theta}^{\frac{\alpha}{\alpha+1}}\left\{\frac{2 \tau_{\mathrm{b}}}{e(\alpha+1) k R_{\mathrm{f}}}\right\}^{\frac{1}{\alpha+1}}\right\}
$$

where

$$
\beta=\sqrt{\frac{2 E_{\mathrm{m}}}{E_{\mathrm{f}}\left(1+\nu_{\mathrm{m}}\right) R_{\mathrm{f}}^{2} \ln \left(\frac{2 \pi}{\sqrt{3} V_{\mathrm{f}}}\right)}}
$$

$\alpha$ and $\sigma_{0}$ are Weibull parameters of the tensile strength of single fibers, $\tau_{b}$ is the interface shear strength, $V_{\mathrm{f}}$ is the fiber volume fraction, $R_{\mathrm{f}}$ is the fiber radius, $\nu_{\mathrm{m}}$ is the Poisson ratio of matrix, and $E_{\mathrm{f}}$ and $E_{\mathrm{m}}$ are the tensile moduli of fiber and matrix, respectively. The value of $k$ was evaluated from the experimental results for the carbon fiber composite strands comprising a series of matrix resins, the tensile modulus of which ranges from about $10 \mathrm{MN} / \mathrm{m}^{2}$ to about $1,000 \mathrm{MN} / \mathrm{m}^{2}$. The value of $k$ changed systematically and increased from $k \simeq 1$ to $k \simeq 20$ with increasing tensile modulus of matrix resin, $E_{\mathrm{m}}$. The change of the $\sigma_{\mathrm{c}, \mathrm{b}}$ of carbon fibers with $E_{\mathrm{m}}$, which was observed experimentally, was rather small. The increase in $E_{\mathrm{m}}$ decreases $\delta$, and this should increase $\sigma_{\mathrm{c}, \mathrm{b}}$. By increasing $E_{\mathrm{m}}$, however, the carbon fibers in the composite strand become to be fractured into a micro-bundle, and this should decrease $\sigma_{c, b}$. It is considered that the change of the $\sigma_{c, b}$ of carbon fibers with $E_{\mathrm{m}}$ is virtually determined by these two, mutually opposed factors. 


\section{1. 緒言}

引張強度吕統計的分布存有する瀻維からなる束の引張 強度は策繊維強度の変動倸数に依存して变化し ${ }^{1}$ ，炭素 織維のように変動係数の大きい織維では，㵶維束の平均 強度は単繊維の平均强度よりもかなり低い值よなる。一 方，竾素瀻維の連続緎維からなる束之比較的剛性の高い 樹脂之を組み合わ甘た複合瀻維束の織維束当りの引張強 度は，一般に瀻維束単独について测定された引張強度上 り专高い值を示す。炭素䄉維一樹脂複合纎維束の引張強 度は、书よそ10 mm以下の試長で测定された単織維の引 張強度に相当する場合が多いようである。

剛直な連続瀻維とこれより延性の高い樹脂をマトリッ タスとした一方向複合材料を瀻維配列方向化伸長すると， たとえばガラス単繊維を樹脂に包埋した大沢らの実験 ${ }^{2)}$, 単層に配列したガラス瀻維在樹脂に包埋したRosenの 実験 ${ }^{3)}$ および炭素纎維〜樹脂複合材料の伸長過程での acoustic emissionに関するFuwaらの実験》などに明 らかな上うに，伸長過程に於いて瀻維は逐次的に破断す

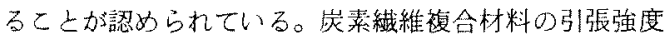
には短い試長で测定された笚䄉維の引張強度が反映され 吕原因は，基本的にはマトリックス内で繊維少古る程度 まで逐次的に破断しても，複合材料全体としては破断す るに至らないととに基づいていると言える。

繊維の逐次破断上複合材料の引張強度上の関連の基本

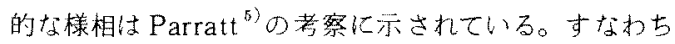
複合材料を伸長すると䋐維は欠宿部で破断するが，破断 点近傍でマトリックスに発生するせん断応力を介して荷 重は破断瀻維間で有效に伝達される。したがってマトリ ックスのせん断応力力䋐維一マトリックス界面のせん断 強度に達するまで瀻維は逐次的汇破断し，界面がせん断 破壊した上きに複合材料が破断する。Rosen ${ }^{3}$ はParratt の考えに更に䄉維引張强度の分布を考愿して複合材料の 破断を考察し，同様の概念汇基づいてLifshitz $ら^{\text {() }}$ はよ り複雑なモードで複合材料か破断する場合について説明 を試みている。Rosenの理論では繊維の破断点近傍で引 張広力在有効比負损しなくなる䋐維部分の長さ，すなわ 占無効織維長に相当する長さの繊維の引張強度を考察す るととによって, 複合材料の引張强度に及保寸マトリッ クスの効果が説明される。

著者らは先に剛性の異なる樹脂をマトリックスよする 一連の炭素瀻維一方向复合材料の層間世九断強度拉よび 引張強度について検討しだ》。その結果，主に破面の観 察に基づいて，複合材料の引張强度を支配するマトリッ クス樹脂特性上の主な因子は，樹脂の剛性が高い場合に は緎維一樹脂界面のせん断强度であり，樹脂の剛性が低
い場合には樹脂のせん断剛性率であると結諭した。この ことから複合材料の引張強度に及ばすマトリックス樹脂

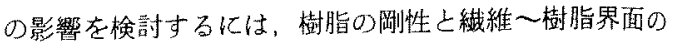
せ九断強度の影響をそれぞれ分けて考えなければならな いこ上が知られる。

本報ではマトリックスの弾性率，織維〜マトリックス 界面のせん断強度捛上び複合材料内の繊維破断端近傍儿 おける応力集中を考愿した破断モデルに基ついて一方向 繊維複合材料の引張強度上単䄉維の引張強度上の関係式

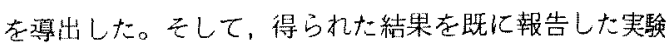
結果 ${ }^{7}$ 亿応用し, 炭素繊維一樹脂複合材料の引張強度に 及ばす樹脂特性の影響について考察した。

\section{2. 実験}

\section{1 炭素纎維}

炭素瀻維にはGrafil EAS (Courtaulds)を用いた。 入手した武料は 10000 本の連続繊維から成る撚りのない トゥ状であって, 单繊維の平均直径は $8.13 \mu \mathrm{m}$ ，密度は $1.82 \mathrm{~g} / \mathrm{cm}^{3}$ であった。

\section{2 单瀻維引張試験}

単瀻維の引張試娩はJISに記载されている方法 ${ }^{8)}$ とほ ぼ同様の方法によって行なった。長さ約 $10 \mathrm{~cm} に$ 切り取 つたトウから任意に採取した単繊維について，ゲージ闒 隔 $10 \mathrm{~mm}$, 引張速度 $5 \% / \mathrm{min}$ として定速伸長型引張試 験機 (テンシロン，東洋ボールドウィン)を用いて引張試 験を行なった。繊維の断面積はへリウムーネオンレーザ 一の回折を応用して,引張試験に用いた各単繊維の残り の長さ部分の最大求よび最小径を测定し，繊維断面をだ 円近似して算出した。

\section{3 複合材料試料の作製および力学的試験}

本報での解析に供した炭菜織維一方向複合材料の層間 せん断强度㧍よび炭素繊維一樹脂複合ストランドの引張 強度の寒験データは，いずれる既報7のデータを引用し た。とれらのデー夕は本報で示す単繊維引張試験に用い たと同じGrafilトウを用いて作製した複合材料試料につ いて得られたあのである。便宜のため試料の作製方法お よび力学的試験の要点記す之以下のでとくである。

マトリックス樹脂には反応性希䣋剂 YED-205に，

Epikote 828あるいはThiokol LPのいずれかを種々の 混合比に調合して用い，マトリックス岡性をゴム状から ガラス状まで広範囲に変化させた。硬化剤には4ーメチ ルヘキサヒドロフタル酸を用いた。っトリックス樹脂の 引張弾性率は，てれらの調合樹脂液を使って樹脂板を作 製して測定した。

原間せん断強度はマッチドダイ法により一方向複合材 料を作彆して直接せん断法により求めた。炭菜瀻維〜樹 
脂複合ストランド(以下，单にストランド)の引張強度は トウ 1 本を樹脂と複合して作製したストランドについて 测定した。

本報告ではストランドの引張强度をストランド構成瀻 維束 (トウ)の単位断面積当りの值，すなっち絨維換算引 張強度しして表わしている。緎維束の断面積は驖維の密 度甫上び䄉維束の線密度加ら算出した。引張強度は最低 10 本の試験片について測定し，結果を平均値扰よび標 隼偏差でした。

\section{3. ストランドの引張強度の理論的考察}

\section{1 破断モデル}

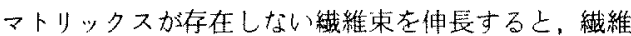
束を構成する瀻維は引張強度の低い瀻維加逐次破断 L ていく。この際，一旦破断した縺維は以降の伸長過程で は織維束の引張荷重奎く分担し得ない。これに刘し， マトリックス樹脂と複合したストランドでは，破断瀻維 端近傍のマトリックスに生しるせん断応力を介して破断 㵶維間に沁力が伝達されるために，既に破断した䋐維で 破断点加充分離れた部分は瀻維束の引張荷重を有效 に分担する。

ストランドにおいて破断繊維が図 1(A)に示寸ように 破断端近傍で引張荷重を分担しなくなる長さ，すなわち 無効緎維長をるで表わす。いま，複合繊維束の繊維軸に 垂直な任意の横断面 $\mathrm{ab}$ 亿注目すると、a b 面を中心とし 長さ $\delta$ の間内に破断点を持つ緎維は，ab面内では引張 荷重を分担していない。しかし，この区間内に破断点を

composite
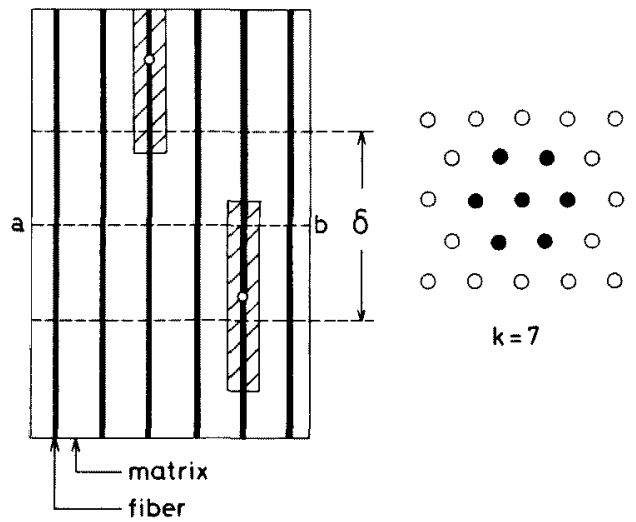

Fig. 1. Schematic illustration of the fracture model of carbon fiber-resin composite strands. (A) Accumulation of fiber fractures. (B) Fibers broken simultaneously in hexagonal array, (O) broken fibers, (O) unbroken fibers.
持たない繊維は，たとえ他の部分で破断していたとして 手 $\mathrm{ab}$ 面内では有效比荷重を分担する。したがって，又 トランドの任意の横断面内で繊維が引張荷重圭分担して いる確率は，ストランドの長さ $\delta$ ○間内で絾維肪破断 していない確率に等しくなる。

ストランド内で 1 本の䋐維加破断する上，破断点近㥬 の繊維は急激な应力集中を受ける。このために1本の瀻 維加破断すると，その破断点を取り閉む $(k-1)$ 本の瀻

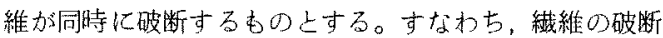
加連銧的隹行することはないとし，1本の繊維加破断 するに伴い合計 $k$ 本の瀻維だけが破断すると仮定する。 図1（B)はストランド内の織維配合をもデル的に示した 四であって，黑丸は破断した繊維を表わす。この図は =7である場合に対応する。

ここで任意の1本の繊維に注目し，との繊維が長さ $\delta$ の区間で破断しない場合を考える。てのような場合は， 注目する㵶維自身がその区閒内で破断せず，乙の繊維を 取り囲む $(k-1)$ 本の㵶維もその区閒内で自ら破断しな い場合である。したがって，1本の織維が長さうの区間 で破断しない確率は， $k$ 本の綫維が長さ $\delta$ の間で自ら 破断しない確率に等しくなる。つまり，ストランドの任 意の横断面内で緎維が有効に引張荷重を分担する確率は， $k$ 本の緎維が長さ $\delta$ の間で自ら破断しない確率に等し w。

さて，ストランドを体舆していくと，ストランド内の 瀻維の引張荷重は增加するか心，任意の横断面内で有効に 引張荷重支えている瀻維数の全繊維数に対する割合は 减少していく。とのためにストランドの引張荷重は，あ る引張荷重で最大攧に達する。この最大值がストランド の司張強度に相当する。

以上の基本的な考元万に徒い，まず無効繊維長 $\delta$ 老决 定し，次にストランド内の任意の横断面で繊維が有効に 引腲荷重を份担寸確率を求め，ついでストランドの引 張強度を導出する。な技义下の議諭ではストランドの引 張荷重に対するマトリックス相の引張荷重の寄与皿視 し，ストラント内の瀻維束の引張㧧度をもってストラン ドの引張强度しする。

\section{2 無効繊維長}

無效繊維長 $\delta$ は破断端近傍での緎維の㐫力分布に基づ いて決定される。ストランド内の1本の繊維に注目する 上次の上うな応力状態が考えられる。充行に長い瀻維が

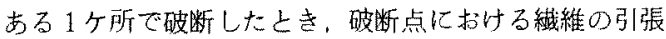
㐫力 $\sigma_{f}^{\prime}$ は0である。破䉼点加ら織維軸に浻って遠ざか るに徉って䄉維の引張応力は增大していき，破断点加ら 䒧分離れた点では破断する直前の絨維の引張応力 $\sigma_{\mathrm{f}}$ に達 する。一方，結維〜マトリックス界面の甘ん断㐫力 $\tau^{\prime}$ 
は破断点から旮分離れた個所では 0 であるが、破断点に 近付くに従って增大し，破断端で最大となる。乙の時, 繊維一マトリックス界面の世ん断応力 $\tau^{\prime}$ が女ん断強度 $\tau_{\mathrm{b}}$ を越える部分では，繊維一マトリックスの仕く離が生ず る。はく離した部分の絨維一マトリックス界面のせん断 応力 $\tau^{\prime}$ はせ九断强度 $\tau_{\mathrm{b}}$ 之等しい值を維持するもの之す る。

問題を単純化するために図 2 に示すモデル化基づいて 䄉維の応力分布老解析する。すなおち注目する半徍 $R_{\mathrm{f}}$ の瀻維を取り囲むマトリックスを外径が $2 R_{\mathrm{m}}$, 内径が $2 R_{\mathrm{f}}$ の円筒之みなし，乙の円筒の外周は繊維軸方向に一 様なひずみ $\sigma_{\mathrm{f}} / E_{\mathrm{f}}$ で变形しているとする。瀻維が六方配

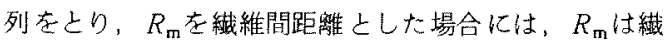
維の体皘含有率 $V_{\mathrm{f}}$ 在用いて $R_{\mathrm{m}}{ }^{2} / R_{\mathrm{f}}{ }^{2}=2 \pi /\left(\sqrt{3} V_{\mathrm{f}}\right)$ 上表 わされる。また破断点在点とし絨維軸に沿って $x$ 軸を 定め, $0 \leqq x \leqq x_{0}$ の範囲で紗維〜マトリックス界面のはく 離が生じているとする。

緎維一マトリックス界面のせん断応力で纎維の変 位 $u_{\mathrm{f}}{ }^{\prime}$ の関倸は以下のように求められる。マトリックス 内部の応力状態は軸対称である。マトリックスは䄉維軸 上垂直な力向には変形しないとする。また、マトリック スはせん断応力のみを伝達するとして、、トリックスの 䄉維軸方向の引張応力を無視する。とれらの仮定任基つ いてマトリックス内部の变位を求めた解には二つの穔分 定数が含まれる。そこで，円筒の外周のひずみが $\sigma_{\mathrm{f}} / E_{\mathrm{f}}$ であるという条件书よび䋐維〜マトリックス界面がはく

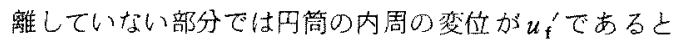
いう条件を満足するようにてれらの棈分定数決定する。 このようにして繊維〜マトリックス界面のせん断応力 $\tau^{\prime}$ 之瀻維の変位 $u_{\mathrm{f}}^{\prime}$ の関係を求める之次式加得られる。

$$
\tau^{\prime}= \begin{cases}\tau_{\mathrm{b}} & \cdots \cdots\left[0, x_{0}\right] \\ \frac{E_{\mathrm{m}}\left(u_{\mathrm{f}}^{\prime}-\frac{\sigma_{\mathrm{f}}}{E_{\mathrm{f}}} x\right)}{\left(1+\nu_{\mathrm{m}}\right) R_{\mathrm{f}} \ln \left(\frac{2 \pi}{\sqrt{3} V_{\mathrm{f}}}\right)} & \cdots \cdot\left[x_{0}, \infty\right]\end{cases}
$$

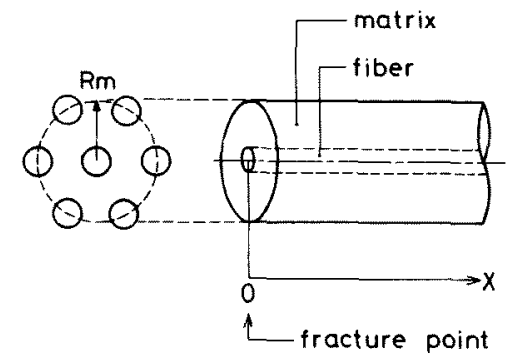

Fig. 2. Model for evaluation of stresses at fiber ends.
繊維の引張応力 $\sigma_{f}{ }^{\prime}$ と瀻維の変位 $u_{\mathrm{f}}{ }^{\prime}$ の開には次式の フック則が成立する。

$$
\sigma_{\mathrm{f}}^{\prime}=E_{\mathrm{f}} \frac{d u_{\mathrm{f}}^{\prime}}{d x}
$$

また，繊維内部の力の釣り合いから次式を得る。

$$
\pi R_{\mathrm{f}}^{2} d \sigma_{\mathrm{f}}{ }^{\prime}-2 \pi R_{\mathrm{f}} \tau^{\prime} d x=0
$$

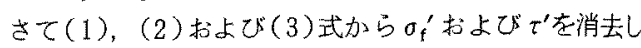
て(4)式を得る。

$$
\frac{d^{2} u_{\mathrm{f}}^{\prime}}{d x^{2}}= \begin{cases}\frac{2 \tau_{\mathrm{b}}}{R_{\mathrm{f}} E_{\mathrm{f}}} & \cdots \cdots\left[0, x_{0}\right] \\ \beta^{2}\left(u_{\mathrm{f}}^{\prime}-\frac{\sigma_{\mathrm{f}}}{E_{\mathrm{f}}} x\right) & \cdots \cdots\left(x_{0}, \infty\right]\end{cases}
$$

ただし，

$$
\beta=\sqrt{\frac{2 E_{\mathrm{m}}}{E_{\mathrm{f}}\left(1+\nu_{\mathrm{m}}\right) R_{\mathrm{f}}^{2} \ln \left(\frac{2 \pi}{\sqrt{3} V_{\mathrm{f}}}\right)}}
$$

境界条件は以下の通りである。

$$
\left\{\begin{array}{l}
x=0 \text { において } \sigma_{\mathrm{f}}{ }^{\prime}=0 \\
x=\infty \text { において } \sigma_{f}^{\prime}=\sigma_{\mathrm{f}} \\
x=x_{0} に お い て \sigma_{f}^{\prime}, \tau^{\prime}, u_{\mathrm{f}}{ }^{\prime} \text { は連続 }
\end{array}\right.
$$

これらの境界条件に基ついて（4）式を解き，ついで(2) 式によって繊維の引張応力 $\sigma_{f}^{\prime}$ を求好る次式が得られ る。

$\sigma_{\mathrm{f}}{ }^{\prime}=\left\{\begin{array}{lr}\frac{2 \tau_{\mathrm{b}}}{R_{\mathrm{f}}} x & \cdots \cdots\left[0, x_{0}\right] \\ -\frac{2 \tau_{\mathrm{b}}}{R_{\mathrm{f}} \beta} \exp \left\{-\beta\left(x-x_{0}\right)\right\}+\sigma_{\mathrm{f}} & \cdots \cdots\left(x_{f}, \infty\right)\end{array}\right.$

ただし，

$$
x_{0}=\frac{R_{\mathrm{f}} \sigma_{\mathrm{f}}}{2 \tau_{\mathrm{b}}}-\frac{1}{\beta}
$$

ことで, $x_{0} \geq 0$ の場合に限ってはく䑾が生ずるので(8) 式より次の条件を得る。

$$
\sigma_{f} \geqq \frac{2 \tau_{\mathrm{b}}}{R_{f} \beta}
$$

繊維軸に沿った全区間で䋐維〜マトリックス界面の甘 几断応力がせん断強度 $\tau_{\mathrm{b}}$ を越えない場合には，界面の はく離は起こらず，(7)および(8)式に $x_{0}=0$ を代入し て(10)式を得る。

$$
\sigma_{\mathrm{f}}{ }^{\prime}=\sigma_{\mathrm{f}}\{1-\exp (-\beta x)\}
$$

ここで，はく離が生じない条件は次のようである。

$$
\sigma_{\mathrm{f}} \leqq \frac{2 \tau_{\mathrm{b}}}{R_{\mathrm{f}} \beta}
$$

ところで， $\sigma_{\mathrm{f}}^{\prime}$ は $x$ 軸に沿って連続的に变化するが，乙 れを次のように近似する。すなわち， $\sigma_{\mathrm{f}}{ }^{\prime} \leqq \sigma_{\mathrm{f}} / 2$ の部分 で $\sigma_{\mathrm{f}}^{\prime}=0, \sigma_{\mathrm{f}}^{\prime}>\sigma_{\mathrm{f}} / 2$ の部分で $\sigma_{\mathrm{f}}{ }^{\prime}=\sigma_{\mathrm{f}}$ とみなす。無効较 
維長 $\partial$ は， $\sigma_{f}^{\prime}=0$ とみなす区間の 2 倍の長さで与えられ る。（7）および(10)式に $\sigma_{\mathrm{f}}{ }^{\prime}=\sigma_{\mathrm{f}} / 2$ を代入し，との時の $x$ が $\delta / 2$ 亿等しいとして $\delta$ を求めると以下のようになる。

$$
\left\{\begin{array}{l}
0 \leqq \sigma_{\mathrm{f}} \leqq \frac{2 \tau_{\mathrm{b}}}{R_{\mathrm{f}} \beta} \text { O時 } \delta=\frac{2 \ln 2}{\beta} \\
\frac{2 \tau_{\mathrm{b}}}{R_{\mathrm{f}} \beta} \leqq \sigma_{\mathrm{f}} \leqq \frac{4 \tau_{\mathrm{b}}}{R_{\mathrm{f}} \beta} \text { の時 } \delta=-\frac{2}{\beta} \ln \left\{\frac{e R_{\mathrm{f}} \beta \sigma_{\mathrm{f}}}{4 \tau_{\mathrm{b}}}\right\}+\frac{R_{\mathrm{f}} \sigma_{\mathrm{f}}}{\tau_{\mathrm{b}}} \\
\frac{4 \tau_{\mathrm{b}}}{R_{\mathrm{f}} \beta} \leqq \sigma_{\mathrm{f}} \text { の時 } \delta=\frac{R_{\mathrm{f}} \sigma_{\mathrm{f}}}{2 \tau_{\mathrm{b}}}
\end{array}\right.
$$

ことで，簡単のために(13)式を(12)あるいは(14)式で 近似すると，次の結論を得る。

$$
\delta=\operatorname{Max}\left[\frac{2 \ln 2}{\beta}, \frac{R_{\mathrm{f}} \sigma_{\mathrm{f}}}{2 \tau_{\mathrm{b}}}\right]
$$

なお，(13)式老(12)あるいは(14)式で近似するととに よる唄差は 9 \%末満である。

\section{3 ストランドの引張強度}

織維の引張強度がワイブル分布汇従うものとすると， 長さ $\delta の$ 織維が応力 $\sigma_{\mathrm{f}}$ で破断しない確率Pは，二つの パラメータ $\alpha ， \sigma_{0}$ を用いて次式のように表わされる。

$$
P=\exp \left\{-\delta\left(\frac{\sigma_{\mathrm{f}}}{\sigma_{0}}\right)^{\alpha}\right\}
$$

ストランドの任意の横断面内で瀻維が引張荷重を分担 している確率 $P^{\prime} は ， k$ 本の䄉維が長さ $\delta$ $の$ 区間で自ら破 断しない確率江等しい。従って,

$$
P^{\prime}=P^{k}=\exp \left\{-k \delta\left(\frac{\sigma_{i}}{\sigma_{0}}\right)^{\alpha}\right\}
$$

が成り立つ。

ストランドの引張応力 $\sigma_{\mathrm{c}}$ は $P^{\prime} と \sigma_{\mathrm{f}}$ の積で与えられる 加

$$
\sigma_{\mathrm{c}}=\sigma_{\mathrm{f}} \exp \left\{-k \delta\left(\frac{\sigma_{\mathrm{f}}}{\sigma_{0}}\right)^{\alpha}\right\}
$$

と表わされる。とのの昆大值がストランドの引張強度 $\sigma_{c, b}$ であるから (18)式に(15)式を代入して次式を得る。

$$
\left\{\begin{array}{l}
\sigma_{0}\left\{\frac{\beta}{2(\ln 2) e \alpha k}\right\}^{\frac{1}{\alpha}} A \leqq \sigma_{0} \frac{\alpha}{\alpha+1}\left\{\frac{2 \tau_{\mathrm{b}}}{e(\alpha+1) k R_{\mathrm{f}}}\right\}^{\frac{1}{\alpha+1}} \\
\text { の時 } \quad \sigma_{\mathrm{c}, \mathrm{b}}=\sigma_{0}\left(\frac{\beta}{2(\ln 2) e \alpha k}\right)^{\frac{1}{\alpha}} \\
\sigma_{0}\left(\frac{\beta}{2(\ln 2) e \alpha k}\right\}^{\frac{1}{\alpha}} B \geqq \sigma_{0} \frac{\alpha}{\alpha+1}\left\{\frac{2 \tau_{\mathrm{b}}}{e(\alpha+1) k R_{\mathrm{f}}}\right\}^{\frac{1}{\alpha+1}} \\
\text { の時 } \sigma_{\mathrm{c}, \mathrm{b}}=\sigma_{0}{ }^{\frac{\alpha}{\alpha+1}}\left(\frac{2 \tau_{\mathrm{b}}}{e(\alpha+1) k R_{\mathrm{f}}}\right\}^{\frac{1}{\alpha+1}}
\end{array}\right.
$$

ここで,

$$
A=\left(\frac{\alpha}{\alpha+1}\right)^{\frac{1}{\alpha+1}} \exp \left\{\frac{1}{\alpha(\alpha+1)}\right\}
$$

$$
B=\left(\frac{\alpha}{\alpha+1}\right)^{\frac{1}{\alpha}} \exp \left\{\frac{1}{\alpha(\alpha+1)}\right\}
$$

であるが， $\alpha \geq 5$ の場合 $1 \%$ 末満の誤差で $A \simeq 1, B \simeq 1$ 上近似できる。したがって，結諭としてストランドの引 張強度は次のように表わされる。

$$
\sigma_{\mathrm{c}, \mathrm{b}}=\operatorname{Min}\left(\sigma_{0}\left\{\left.\frac{\beta}{2(\ln 2)_{e \alpha k}}\right|^{\frac{1}{\alpha}}, \sigma_{0}^{\frac{\alpha}{\alpha+1}}\left(\frac{2 \tau_{\mathrm{b}}}{\varepsilon(\alpha+1) k R_{\mathrm{f}}}\right\}^{\frac{1}{\alpha+1}}\right\}\right.
$$

\section{4. 実験との対応}

\section{1 单瀻維引張試験}

単紻維の引張強度がワイブル分布に従うとすれば，長 さ $L$ の䋐維が沁力 $\sigma_{\mathrm{f}}$ 以下で破断する確率 $F$ は次式を満 足する。

$$
\ln \left\{-\frac{1}{L} \ln (1-F)\right\}=\alpha \ln \sigma_{\mathrm{f}}-\alpha \ln \sigma_{0}
$$

すな和ち, $\ln \sigma_{\mathrm{f}}$ に対して $\ln \left\{-\frac{1}{L} \ln (1-F)\right\}$ をプロッ トしたグラフは直線となる。图了は試長 $10 \mathrm{~mm}$ 単瀻維 引張強度について，ての上うなプロット老行なった結果 である。各測定值が 1 本の直線上に位置しているととか ら，この炭素瀻維の引張强度分布がワイブル分布で近似 できるととがわかる。直線の勾配および切片から， $\alpha=$ $5.42, \sigma_{0}=1.37\left(\mathrm{GN} / \mathrm{m}^{2} \cdot \mathrm{m}^{\frac{1}{\alpha}}\right)$ を得る。

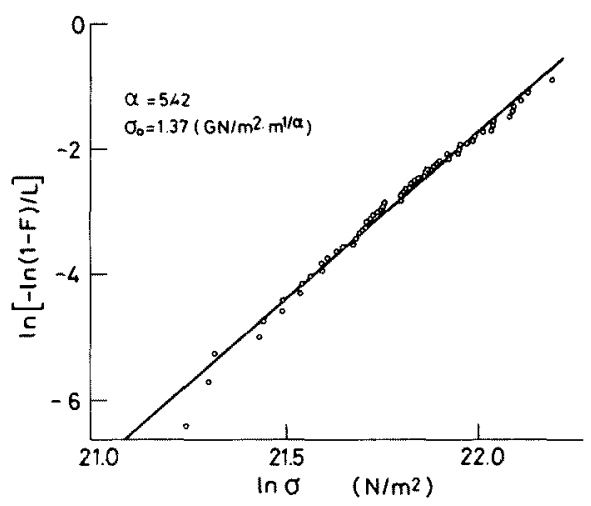

Fig. 3. Weibull plot of the tensile strength of carbon fibers.

\section{2 ストランドの引張強度}

图 4 は層間甘ん断強度 $\tau_{\mathrm{b}}$ をマトックスの引張弾性率 $E_{\mathrm{m}}$ に対してプロットした結果である。とてろで(20)式 で与えられたように、ストランドの引張強度 $\sigma_{\mathrm{c}, \mathrm{b}}$ は， $\tau_{\mathrm{b}}$ あるいは $E_{\mathrm{m}}$ に依存して定まる值のいずれか小さい方で 与えられ，雨者の境界は $(20)$ 式より，次式で表わされる。

$$
\tau_{\mathrm{b}}=\frac{\sigma_{0} e(\alpha+1) k R_{\mathrm{f}}}{2}\left\{\frac{\beta}{2(\ln 2) e \alpha k}\right\}^{\frac{\alpha+1}{\alpha}}
$$




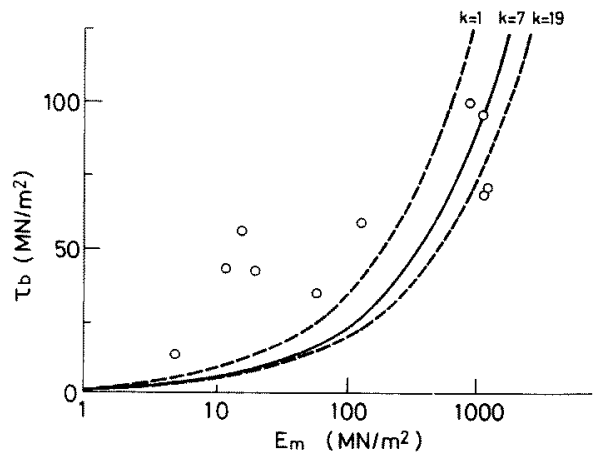

Fig. 4. Plot of the interlaminar shear strength $\tau_{b}$ against the tensile modulus $E_{\mathrm{m}}$ of matrix resin for carbon fiber-resin unidirectional composites.

図4に実線で示したグラフは(22)式により， $k=7$, $\nu_{\mathrm{m}}=0.4$ ， その他の所要のパラメータには実験值を用い て算出した值である。なお同図には参考までに $k$ 値のみ をk=1および 19 之変化させ，その他のパラメ一夕は $k$ $=7$ の場合に同じ値を用いて算出したグラフを破線で示 してある。境界線の上側の領域に $\tau_{\mathrm{b}} \sim E_{\mathrm{m}}$ 関保が位監す る試料では, ストランドの引張強度が $E_{\mathrm{m}}$ 亿依存し，下 側の領域に位置する試料では $\tau_{\mathrm{b}} に$ 依存することを意味す る。

ストランドの引張强度 $\sigma_{c, \mathrm{~b}}$ がマトリックスの引張弾性 率 $E_{\mathrm{m}}$ に依存して定まる陚料について， $\sigma_{c, b}$ を $E_{\mathrm{m}}$ に対し てプロットした結果が図 5 である。図中の曲線は (20)式 により算出した引張强度である。ただし計算には，先と 同様に $k=7, \nu_{\mathrm{m}}=0.4$ とし, その他のパラメータには実 測值老用いた。

図 5 に見られるように $k=7$ と見積って算出したスト ランドの引張強度は実測值のレベルとほぼ一致している。

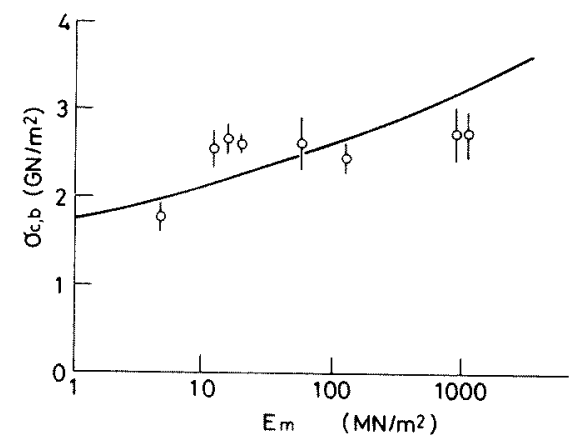

Fig. 5. Plot of the effective tensile strength $\sigma_{c, b}$ of carbon fibers in carbon fiber-resin composite strands against the tensile modulus $E_{\mathrm{m}}$ of matrix resin.

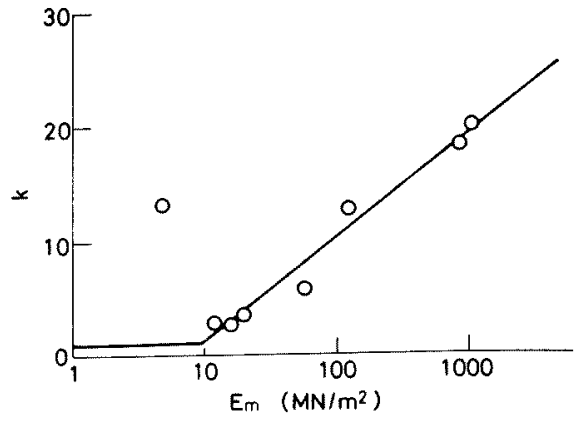

Fig. 6. Variation of the factor $k$ with the tensile modulus $E_{\mathrm{m}}$ of matrix resin.

しかし培細に見るとマトリックスの引張弾性率 $E_{\mathrm{m}}$ が約 $100 \mathrm{MN} / \mathrm{m}^{2}$ より低い試料ではストランドの引張強度は 実測值の方が計算值より高い倾向にあり，また $E_{\mathrm{m}}$ が100 $\mathrm{MN} / \mathrm{m}^{2}$ より高い試料では逆侄計算值より実測值の方が 低い傾向汇ある。そてで， $k$ の值肪 $E_{\mathbf{m}}$ に対して変化す ると考えて，(20)式によって計算されるストランドの引 張強度之実測された引張强度が一致するような $k$ の值を それそれれの試料につてて計算した。図6はてのようにし て得られた $k$ の値をマトリックスの引張弾性率 $E_{\mathrm{m}}$ 亿対 してプロットした結果である。 $k$ の值が $E_{\mathrm{m}}$ に対して系 統的に变化しているととから， $k$ の值は $E_{\mathrm{m}}$ に依存する と見るととができる。

\section{5. 考察}

破断モデルに於いて $k$ 值を定義したように，ある1本 の繊維が破断すると同時に，乙れ在取り囲む 1 層の織維 が破断する場合は $k=7$ となる。さらに第 2 層の瀻維ま でが破断する場合は $k=19$ 亡なる。したがって図 6 亿得 た $k \sim E_{\mathrm{m}}$ 関係加ら，䋐維破断の様相は次のようであると 解粎される。すなわち $E_{\mathrm{m}} \simeq 10 \mathrm{MN} / \mathrm{m}^{2}$ ではストランド 内で織維が離散的に逐次破断し, $E_{\mathrm{m}} \simeq 100 \mathrm{MN} / \mathrm{m}^{2}$ では 核となる破断瀻維を取り囲む1層の瀻維が破断し， $E_{\mathrm{m}} \simeq$ $1000 \mathrm{MN} / \mathrm{m}^{2}$ では第 2 層までの織維が同時化破断する。 ストランド構成繊維間の相互作用は $E_{\mathrm{m}}$ が低くなるほど 小さいから， $E_{\mathrm{m}} \leqq 1 \mathrm{MN} / \mathrm{m}^{2}$ では $k=1$ と見なすのが妥 当であるう。

ところで形式的に(17)式は無効繊維長 $\delta$ が俰数 $k$ だけ 変化すると見るとともできるから，図 6 の結果は $E_{\mathrm{m}}$ が 增大するにつれて無效繊維長が(15) 式で見積られる值よ りあ実際には $k$ 倍の值をとると解釈することも可能であ る。無効繊維長が大きな值をとるとすれば，その原因は 繊維〜マトリックス界面の接着が允分でないととに基う く。しかし、ストランドの破面を観察した結果 ${ }^{7}$ にる 上， $E_{\mathrm{m}}$ 名比較的低い場合 $\left(50 \mathrm{MN} / \mathrm{m}^{2}\right.$ 程度)には破面が 
平面的であり，層間せん断破面の状態から見ても瀻維〜 樹脂界面がはく嶉している可能性は低い。また $E_{\mathrm{m}} \simeq 1000$ $\mathrm{MN} / \mathrm{m}^{2}$ 程度の樹脂をマトリックスとするストランドに 於いても，ストランドの破面に複数の縉維がマトリック 又と同じ平面で一体的に破断している個所(既報 ${ }^{7}$ ，図 10)加認められる。これらを考慮すると，はじめに定義 したように係数 $k$ は一体的に破断する瀻維の本数とする のか罗当と考えられる。

さて図 5 に示したストランドの引張強度 $\sigma_{\mathrm{c}, \mathrm{b}}$ とマトリ ッ㮹脂の引張弾性率 $E_{\mathrm{m}}$ 上の関係に見出さ机るよう に， $\sigma_{\mathrm{c}, \mathrm{b}}$ の実測值は $E_{\mathrm{m}}$ に対する依存性が小さい。との 原因はこれまでの考察に基ついて以下のように説明され る。すなわち $E_{\mathrm{m}}$ が增大すると無効械維長は减少し，乙 のととは $\sigma_{\mathrm{c}, \mathrm{b}}$ 增大させる方向化作用する。一方， $E_{\mathrm{m}}$ が増大するにつれて強度の低い織維がストランド内で破 断すると，その衝撃によって周辺の緎維が “束切れ”を 起こすようになり，てれは $\sigma_{c, b}$ を低下させる方向に作用す る。したがって，雨者のか的合いにより $\sigma_{c, b}$ の実測值は $E_{\mathrm{m}}$ に対する依存性が低く現われたと言える。とのとと は，本報で検討したような樹脂との接着性が比較的良好 である緎維では，複合材料内部で緎維の“束切れ”が生 じないような複合構造をとらすととが、瀻維の強度を最 ま有効汇利用する上汇重要であるととを示哮している。

\section{6. 総 括}

マトリックスの弾性率, 䋐維一マトリックス界面のせ ん断強度および複合材料内の紻維破断端近傍における応 力集中を考虑した破断モデルに基づいて炭素䋐維単瀻維 の引張強度と炭素䋞維〜樹脂複合ストランドの引張強度 との関係式を導出した。その結果を剛性の異なる樹脂を マトリックスとする一連のストランドの引張強度関す
る実験結果に応用し、ストランドの引張強度に及ばす樹 脂特性の影留について考察した。ストランドの引張强度 の実測値はマトリックスの引張弹性率江対する侤存性が 低加った。トリックスの引張弾性率加增大寸る之無効 繊維長が短くなり，とのことはストランドの引張強度を 增大させる方向に作用する。一方，マトリックスの引張 弹性率が增大するにつれて、ストランド内で强度の低い 織維が破断するとその衝䡈によって周辺の繊維が “束切 れ”を起こすようになり，とのととはストランドの引張 強度を低下させる方向に作用する。これらの相反する二 つの因子の兼合いによって，実際の炭素繊維ストランド の引張強度とマトリックス樹脂の引張弹性率との関係が 決定されていると結論した。

付虽：本研究の一部は文部省科学研究賢総合 (A)によ った。

\section{文献}

1) B. D. Coleman; J. Mech. Phys. Solids., 7, 60 (1958).

2)大沢直志，中山晃，三輪実，長谷川明; 繊学 誌, 33, T-6 (1977).

3) B. W. Rosen; AIAA J., 2, 1985 (1964).

4) M. Fuwa, B. Harris and A. R. Bunsell; J. Phys. $D, 8,1460$ (1975).

5) N. J. Parratt; Rubber Plastics Age, pp. 263266, March (1960).

6) J. M. Lifshitz and A. Rotem; J. Mater. Sci., 7, 861 (1972).

7) 高久 明，塩谷正俊。清水二郎；緎学誌， 39，T315 (1983)

8) 炭素䋐維試験方法 (5.3.1 単瀻維試験方法) JIS R $7601-1980$. 